Ю.В. Авдосьєв ${ }^{1}$, К.М. Паньків ${ }^{2}$

${ }^{1}$ Державна установа «Інститут загальної та невідкладної хірургії імені В.Т. Зайцева НАМн України», Харків ${ }^{2}$ Вінницький національний медичний університет імені М.І. Пирогова

\title{
Прогнозування тяжкості перебігу гострого аліментарного панкреатиту на основі лабораторних показників
}

Мета - оцінити зміни лабораторних показників у пацієнтів з гострим панкреатитом (ГП) аліментарного генезу при повторних вимірюваннях та визначити їх роль у прогнозуванні тяжкості перебігу. Об'єкт і методи досліджен-

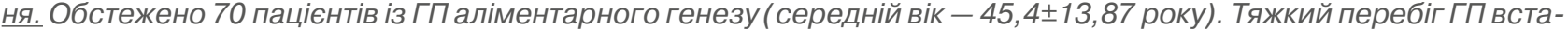
новлено у 34 (48,57\%), середній - у 25(35,72\%), легкий - у 11 (15,71\%) осіб. Тяжкість перебігу оцінювали за допомогою класифікації Атланта 2012 р. Для прогнозування тяжкості ГП проводили повторні вимірювання рівнів паличкоядерних нейтрофілів, амілази та глюкози. Результати. Достовірно вищу ймовірність легкого перебігу ГП встановлено упацієнтів зі значеннями паличкоядерних нейтрофілів <7\%, амілази <64 од. та глюкози <3,3 ммоль/л при первинному зверненні та протягом лікування. Доведені прогностичні критерії середньої тяжкості - значення глюкози 3,3-5,5 ммоль/л при первинному вимірюванні та в процесі лікування. Ухворих зі значеннями паличкоядерних нейтрофілів $\geqslant 7 \%$, амілази >64 од. та глюкози $\geqslant 5,5$ ммоль/л при первинному вимірюванні та в процесі лікування доведено достовірно вищу ймовірність тяжкого перебігу захворювання. Критеріями тяжкого перебігу також є підвищені рівні паличкоядерних нейтрофілів і глюкози після завершення лікування. Висновки. Доведено високу інформативність лабораторних показників у прогнозуванні тяжкості ГП та їх достовірну відмінність у досліджуваних групах.

Ключові слова: гострий аліментарний панкреатит, прогнозування тяжкості перебігугострого панкреатиту, ступінь тяжкості гострого панкреатиту, лабораторні показники.

\section{Вступ}

Рання діагностика, ефективне лікування та профілактика гострого панкреатиту (ГП) - актуальні проблеми сучасної хірургії, що зумовлено високою частотою ускладненого перебігу та значною інвалідизацією населення працездатного віку (van Dijk S.M. et al., 2017). Епідеміологічні дослідження останніх десятиліть свідчать про неухильний ріст частоти випадків ГП в цілому та збільшення його аліментарно-асоційованих форм зокрема (Petrov M.S., Yadav D., 2019). Зростання рівня аліментарного ГП спричинено численними факторами, основними з яких є незбалансоване харчування та порушення його режиму, надмірне вживання твердих жирів, дефіцит білкової складової раціону, голодування, зловживання алкоголем тощо.

Рівень летальності при ГП варіює в діапазоні 4,5-15\%, при деструктивних формах сягає 24-60\%, при інфікованому панкреонекрозі-85\%, а при фульмінантному перебігу ГП - 100\% (Shah A.P. et al., 2018; Petrov M.S., Yadav D., 2019). Незважаючи на широкий арсенал хірургічних технік та впровадження нових методик лікування, летальність після оперативного втручання становить 70$86 \%$ і не має тенденції до зниження (Staubli S.M. et al., 2015). Основними причинами летальності на ранніх етапах захворювання є шок та поліорганна недостатність, а в деструктивній стадії гнійно-септичні ускладнення. Факторами, що зумовлюють високу летальність, вважають несвоєчасну діагностику, неадекватне консервативне лікування, відсутність єдиного підходу до вибору оперативного способу лікування - його обсягу і термінів виконання.

Вибір правильної тактики лікування та запобігання ускладненням можливі лише на основі ранньої діагностики захворювання, визначення його форми, глибини деструктивних змін у підшлунковій залозі (ПЗ) та заочеревинній клітковині. Сучасні алгоритми лікування ГП базуються на визначенні ступеня тяжкості захворювання та наявності ускладнень (Cho J.H. et al., 2015; Greenberg J.A. et al., 2016). Для вибору оптимального методу лікування необхідне ретельне загальноклінічне обстеження пацієнта й оцінка структурно-функціонального стану ПЗ, її паренхіми, судинної архітектоніки басейну черевного стовбура аорти та верхньої брижової артерії, особливості стінки дванадцятипа- лої кишки, гіпертензії панкреатичного, біліарного чи портального генезу (Karakayali F.Y., 2014). Важливо враховувати, що розвиток ГП не обмежується ізольованим ураженням ПЗ, а має полісистемний характер (Гончаров М.П., Шведа Ю.І., 2016). Значну частку серед позаорганних уражень займають порушення в системі фібринолізу та гемостазу. У пацієнтів із тяжким перебігом ГП відбуваються порушення в гуморальній та клітинній ланках імунітету, що погіршують перебіг захворювання (Manohar M. et al., 2017).

Своєчасна діагностика ГП - одна з найскладніших проблем сучасної ургентної абдомінальної хірургії. Доведених клініко-лабораторних критеріїв диференційної діагностики обмеженої та поширеної, асептичної і септичної форм ГП не розроблено (Cho J.H. et al., 2015; Shah A.P. et al. 2018). Пріоритетними в діагностиці залишаються клінічні прояви захворювання - характерний анамнез та дані об'єктивного обстеження.

Значення лабораторних показників не вважають ідеальними маркерами в діагностиці ГП у зв'язку з високою вірогідністю хибних результатів та їх низькою специфічністю (Staubli S.M. et al., 2015; Rompianesi G. et al., 2017). Однак аналіз їх ролі у прогнозуванні тяжкості перебігу аліментарного ГП є актуальною проблемою у зв'язку з простотою визначення, високою доступністю та можливістю ранньої інтерпретації результатів. Таким чином, визначення ролі стандартних лабораторних показників у прогнозуванні ступеня тяжкості ГП є актуальною проблемою та потребує подальшого вивчення.

Мета - оцінити зміни лабораторних показників у пацієнтів із аліментарним ГП при повторних вимірюваннях та визначити їх роль у прогнозуванні тяжкості перебігу.

\section{Об'єкт і методи дослідження}

Проаналізовано особливості перебігу та результати лікування 70 пацієнтів із ГП аліментарного генезу, які перебували на стаціонарному лікуванні в хірургічному відділенні Вінницької обласної клінічної лікарні імені М.І. Пирогова в період 20142017 рр. У досліджувану групу включено $48(68,57 \%)$ чоловіків та $22(31,43 \%)$ жінки (середній вік $-45,4 \pm 13,87$ року). Усі паці- 
єнти ретельно обстежені, тактика лікування відповідала вимогам клінічного протоколу надання медичної допомоги пацієнтам із ГП, згідно з наказом Міністерства охорони здоров'я України від 02.04.2010 р. № 297.

Обстежених включено у три групи з урахуванням тяжкості перебігу аліментарного ГП. У більшості осіб встановлено тяжкий 34 (48,57\%), у $25(35,72 \%)$ - середній, у 11 (15,71\%) - легкий перебіг ГП. Тяжкість перебігу ГП встановлювали за допомогою класифікації Атланта 2012 р. (Greenberg J.A. et al., 2016).

Для прогнозування перебігу аліментарного ГП проводили повторні визначення рівнів паличкоядерних нейтрофілів (ПН), амілази та глюкози крові. Вимірювання лабораторних показників проводили при первинному зверненні, протягом лікування та на завершальному етапі.

Згідно з результатами тесту Колмогорова - Смірнова розподіл досліджуваної групи відрізнявся від нормального з високим ступенем вірогідності ( $p<0,05)$. При порівнянні показників незалежних груп використовували непараметричні критерії Краскела - Уолліса та Манна - Уїтні. Для оцінки наявності зв'язку між ступенем тяжкості ГП та значеннями лабораторних показників застосовували коефіцієнт кореляції т-Кендалла. Прогнозування тяжкості перебігу ГП виконували на основі лабораторних показників із застосуванням статистичної моделі логістичної регресії. Шляхом розрахунку відношення шансів (ВШ) та 95\% довірчих інтервалів (ДІ) проведено кількісну оцінку зв'язку досліджуваних лабораторних показників із тяжкістю перебігу аліментарного ГП Кожний фактор оцінювали окремо. Лабораторні показники аналізували при повторних вимірюваннях. Вірогідність безпомилкового прогнозу визначали при $p<0,05$. Для статистичного аналізу отриманих даних використовували програму «Statistica 10».

\section{Результати та їх обговорення}

При первинному зверненні середній рівень ПН у крові пацієнтів досліджуваної групи становив $12,13 \pm 9,63 \%$, підвищення рівня відзначено у більшості обстежених - 58 (82,86\%), у решти $12(17,14 \%)$ - значення зберігалися в межах референтної норми (табл. 1). При порівнянні середніх показників ПН, визначених при первинному зверненні, з урахуванням ступеня тяжкості між показниками встановлено статистично значиму різницю $(p=0,01)$ У хворих із тяжким перебігом ГП відзначено достовірно вищу частоту підвищених показників ПН при госпіталізації $(p=0,01)$. Між ступенем тяжкості ГП та значеннями ПН встановлено прямий кореляційний зв'язок слабкої сили ( $\tau=0,23 ; p=0,005)$, що свідчить про достовірне зростання рівня ПН зі збільшенням тяжкості перебігу ГП.

Таблиця 1. Оцінка рівня ПН у пацієнтів 3 аліментарним ГП з урахуванням тяжкості перебігу

\begin{tabular}{|c|c|c|c|c|}
\hline \multirow{2}{*}{ Значення } & \multicolumn{3}{|c|}{ Ступінь тяжкості } & \multirow{2}{*}{ p } \\
\hline & легкий & середній & тяжкий & \\
\hline \multicolumn{5}{|c|}{ 1-ше вимірювання } \\
\hline $\mathrm{M} \pm \mathrm{SD}$ & $7,36 \pm 3,50$ & $11,44 \pm 8,47$ & $14,18 \pm 11,20$ & $0,04^{*}$ \\
\hline $1-6 \%$ & $5(45,45 \%)$ & $5(20,0 \%)$ & $2(5,88 \%)$ & $0,01^{\star}$ \\
\hline$\geqslant 7 \%$ & $6(54,55 \%)$ & $20(80,0 \%)$ & $32(94,12 \%)$ & $0,01^{*}$ \\
\hline \multicolumn{5}{|c|}{ 2-ге вимірювання } \\
\hline $\mathrm{M} \pm \mathrm{SD}$ & $6,73 \pm 3,72$ & $9,96 \pm 8,39$ & $12,94 \pm 7,49$ & $0,004^{*}$ \\
\hline $1-6 \%$ & $7(63,64 \%)$ & $10(40,0 \%)$ & $5(14,71 \%)$ & $0,006^{*}$ \\
\hline$\geqslant 7 \%$ & $4(36,36 \%)$ & $15(60,0 \%)$ & $29(85,29 \%)$ & $0,006^{*}$ \\
\hline \multicolumn{5}{|c|}{ 3-тє вимірювання } \\
\hline $\mathrm{M} \pm \mathrm{SD}$ & $1,09 \pm 0,94$ & $2,24 \pm 1,64$ & $4,65 \pm 3,37$ & $<0,00001^{*}$ \\
\hline $1-6 \%$ & $11(100,0 \%)$ & $24(96,0 \%)$ & $27(79,41 \%)$ & 0,06 \\
\hline$\geqslant 7 \%$ & - & $1(4,0 \%)$ & $7(20,59 \%)$ & 0,06 \\
\hline
\end{tabular}

*У табл. 1-6: достовірна відмінність показників при p<0,05

При вимірюванні у процесі лікування показники ПН залишалися підвищеними в усіх групах, однак спостерігали їх поступове зниження порівняно з попередніми даними. Середній

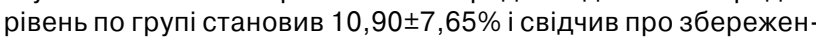
ня активного запального процесу у пацієнтів досліджуваної групи. Підвищення досліджуваних показників зареєстровано у більшості пацієнтів із тяжким - 29 (85,29\%) та 15 (60,0\%) пацієнтів із середнім ступенем тяжкості аліментарного ГП, натомість збереження значень у межах норми встановлено у 5 (14,71\%) та 10 (40,0\%) обстежених відповідних груп. Активне запалення зберігалося у $4(36,36 \%)$ пацієнтів із легким перебігом захворювання, у більшості - 7 (63,64\%) - показники відповідали референтним межам норми. При порівнянні поширеності підвищених показників та частоти значень, що відповідали референтним межам, встановлено достовірну відмінність результатів $(p=0,006)$. При порівнянні середніх рівнів ПН найвищі показники спостерігали у хворих із тяжким перебігом - 12,94ะ7,49\%. У пацієнтів із середнім та легким перебігом показники теж залишалися підвищеними -

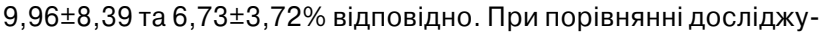
ваних показників встановлена відмінність статистично значима $(p=0,004)$. Наявність прямого кореляційного зв'язку середньої сили ( $\tau=0,31 ; p=0,0001)$ між ступенем тяжкості ГП та рівнем ПН свідчить про достовірне підвищення рівня ПН у пацієнтів зі збільшенням ступеня тяжкості захворювання при вимірюванні у процесі лікування.

Середній рівень показників ПН по завершенню лікування

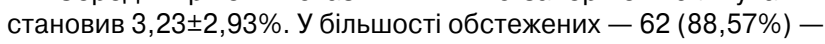
рівень ПН відповідав референтним межам норми, у $8(11,43 \%)-$ зберігалося підвищення досліджуваних показників. Різниця між показниками ПН, визначеними після проведеного лікування, з урахуванням тяжкості перебігу захворювання статистично значима $(p<0,00001)$. Встановлено наявність прямого кореляційного зв'язку середньої сили ( $\tau=0,49 ; p \leqslant 0,00001)$ між ступенем тяжкості ГП та рівнем ПН, що свідчить про достовірне підвищення рівня ПН у пацієнтів зі збільшенням ступеня тяжкості захворювання. У групі хворих із тяжким перебігом ГП зафіксовано достовірно вищу частоту підвищених показників ПН навіть по завершенню лікування $(p=0,06)$.

Середній рівень амілази при госпіталізації у пацієнтів досліджуваної групи становив 318,86ะ383,15 од. (табл. 2). Підвищення показників зареєстровано у 51 (72,86\%) хворого, у $20(27,14 \%)$ показники зберігалися в межах референтних значень. Підвищення показників амілази спостерігали в більшості пацієнтів усіх груп у $5(45,45 \%)$ осіб з легким, у 16 (64,0\%) - з середнім та у $13(38,24 \%)$ - з тяжким перебігом ГП, різниця між показниками достовірна $(p=0,01)$. Найвищі показники амілази відзначено

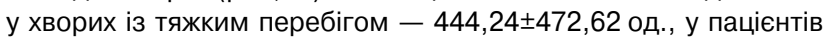
з легким та середнім ступенем тяжкості значення амілази також

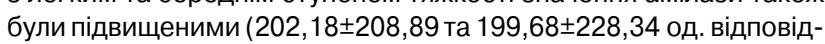
но). При порівнянні показників амілази у групах з урахуванням ступеня тяжкості ГП встановлено статистично значиму різницю $(p=0,04)$. Доведено, що підвищення тяжкості перебігу ГП достовірно пов'язано зі зростанням рівня амілази крові (т=0,25; $p=0,002)$.

Таблиця 2. Оцінка рівня амілази крові в пацієнтів з аліментарним ГП з урахуванням тяжкості перебігу

\begin{tabular}{|c|c|c|c|c|}
\hline \multirow{2}{*}{ Значення } & \multicolumn{3}{|c|}{ Ступінь тяжкості } & \multirow{2}{*}{ p } \\
\hline & легкий & середній & тяжкий & \\
\hline \multicolumn{5}{|c|}{ 1-ше вимірювання } \\
\hline $\mathrm{M} \pm \mathrm{SD}$ & $202,18 \pm 208,89$ & $199,68 \pm 228,34$ & $444,24 \pm 473,62$ & $0,04^{*}$ \\
\hline$\leqslant 64$ од. & $6(54,55 \%)$ & $9(36,0 \%)$ & $4(11,76 \%)$ & $0,01^{\star}$ \\
\hline$>64$ од. & $5(45,45 \%)$ & $16(64,0 \%)$ & $30(88,24 \%)$ & $0,01^{\star}$ \\
\hline \multicolumn{5}{|c|}{ 2-ге вимірювання } \\
\hline $\mathrm{M} \pm \mathrm{SD}$ & $37,82 \pm 35,79$ & $180,80 \pm 284,31$ & $336,47 \pm 442,20$ & $0,0009^{*}$ \\
\hline$\leqslant 64$ од. & $10(90,91 \%)$ & $15(60,0 \%)$ & $13(38,24 \%)$ & $0,008^{*}$ \\
\hline$>64$ од. & $1(9,09 \%)$ & $10(40,0 \%)$ & $21(61,76 \%)$ & $0,008^{*}$ \\
\hline \multicolumn{5}{|c|}{ 3-те вимірювання } \\
\hline $\mathrm{M} \pm \mathrm{SD}$ & $21,09 \pm 8,96$ & $33,92 \pm 26,16$ & $46,12 \pm 31,70$ & $0,009^{*}$ \\
\hline$\leqslant 64$ од. & $11(100,0 \%)$ & $24(96,0 \%)$ & $31(91,18 \%)$ & 0,49 \\
\hline$>64$ од. & - & $1(4,0 \%)$ & $3(8,82 \%)$ & 0,49 \\
\hline
\end{tabular}

При вимірюванні значень амілази у процесі лікування середній показник по групі становив 233,94ะ366,28 од. У пацієнтів з легким перебігом середній рівень амілази становив $37,82 \pm 35,79$ од. та відповідав референтним межам у більшості хворих - $10(90,91 \%)$, гіперамілаземія зберігалася у $1(9,09 \%)$ пацієнта. У хворих з тяжким та середнім ступенем тяжкості середні значення амілази залишалися підвищеними -

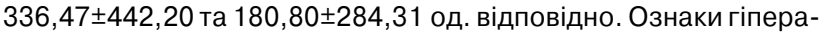
мілаземії зберігалася у більшості пацієнтів з тяжким перебігом ГП - у $21(61,76 \%)$ та у $10(40,0 \%)$ із середнім ступенем тяжкості. Значення амілази, що відповідали референтним межам, зареєстровано у 15 (60,0\%) обстежених із середнім ступенем тяжкості аліментарного ГП та 13 (38,24\%) з тяжким перебігом. При порівнянні середніх значень $(p=0,0009)$ та поширеності 
значень, що відповідали референтним межам норми ( $p=0,008)$, та ознак гіперамілаземії $(p=0,008)$ встановлено достовірну відмінність показників з урахуванням тяжкості перебігу. Встановлено прямий кореляційний зв'язок середньої сили ( $\tau=0,36$; $\mathrm{p}=0,00001)$ між тяжкістю ГП та рівнем амілази в крові, визначеним у процесі лікування, що свідчить про достовірне зростання рівня амілази з підвищенням ступеня тяжкості перебігу захворювання.

Після проведеного лікування середній рівень амілази крові у пацієнтів досліджуваної групи становив $37,83 \pm 28,53$ од. та відповідав референтним значенням норми. При порівнянні показників амілази крові, встановлених після проведеного лікування, у групах пацієнтів з урахуванням ступеня тяжкості встановлено статистично значиму різницю $(p=0,009)$. У пацієнтів із тяжким перебігом ГП відзначено достовірно вищі показники амілази крові навіть після проведеного лікування. Між ступенем тяжкості ГП та показниками амілази крові у пацієнтів досліджуваної групи встановлено прямий кореляційний зв'язок середньої сили ( $\tau=0,32 ; p=0,00009)$, який свідчить про достовірне зростання рівня амілази з підвищенням ступеня тяжкості перебігу захворювання.

При первинному вимірюванні глюкози крові у пацієнтів досліджуваної групи її середній рівень становив $5,13 \pm 2,01$ ммоль/л (табл. 3). У 32 (45,72\%) обстежених значення відповідали референтним межам норми, ознаки гіперглікемії встановлено у $33(47,14 \%)$, гіпоглікемії - у 5 (7,14\%) обстежених. При порівнянні середніх показників з урахуванням ступеня встановлено достовірну різницю між показниками $(p=0,03)$. У хворих з тяжким перебігом спостерігали достовірно вищу частоту підвищених показників $(p=0,003)$, натомість у пацієнтів з легкою формою достовірно частіше реєстрували ознаки гіпоглікемії $(p=0,03)$. У пацієнтів з тяжчим перебігом ГП встановлено достовірно вищі показники глюкози, що підтверджено наявністю прямого кореляційного зв'язку слабкої сили ( $\tau=0,26 ; p=0,001)$.

Таблиця 3. Оцінка рівня глюкози крові у пацієнтів з аліментарним ГП з урахуванням тяжкості перебігу

\begin{tabular}{|c|c|c|c|c|}
\hline \multirow{2}{*}{ Значення } & \multicolumn{3}{|c|}{ Ступінь тяжкості } & \multirow{2}{*}{$\mathbf{p}$} \\
\hline & легкий & середній & тяжкий & \\
\hline \multicolumn{5}{|c|}{ 1-ше вимірювання } \\
\hline $\mathrm{M} \pm \mathrm{SD}$ & $4,25 \pm 1,13$ & $4,77 \pm 1,32$ & $6,06 \pm 2,37$ & $0,03^{*}$ \\
\hline$<3,3$ ммоль/л & $3(27,27 \%)$ & $1(4,0 \%)$ & $1(2,94 \%)$ & $0,02^{*}$ \\
\hline 3,3-5,5 ммоль/л & $6(54,55 \%)$ & $16(64,0 \%)$ & $10(29,41 \%)$ & $0,03^{*}$ \\
\hline$>5,5$ ммоль/л & $2(18,18 \%)$ & $8(32,0 \%)$ & $23(67,65 \%)$ & $0,003^{*}$ \\
\hline \multicolumn{5}{|c|}{ 2-ге вимірювання } \\
\hline $\mathrm{M} \pm \mathrm{SD}$ & $4,77 \pm 2,21$ & $4,83 \pm 1,64$ & $6,18 \pm 2,97$ & $0,03^{*}$ \\
\hline$<3,3$ ммоль/л & $1(9,09 \%)$ & $2(8,0 \%)$ & $1(2,94 \%)$ & 0,62 \\
\hline 3,3-5,5 ммоль/л & $9(81,82 \%)$ & $21(84,0 \%)$ & $18(52,94 \%)$ & $0,03^{*}$ \\
\hline$>5,5$ ммоль/л & $1(9,09 \%)$ & $2(8,0 \%)$ & $15(44,12 \%)$ & $0,003^{*}$ \\
\hline \multicolumn{5}{|c|}{ 3-те вимірювання } \\
\hline $\mathrm{M} \pm \mathrm{SD}$ & $4,30 \pm 1,86$ & $4,59 \pm 1,15$ & $5,54 \pm 2,68$ & 0,08 \\
\hline$<3,3$ ммоль/л & $2(18,18 \%)$ & $3(12,0 \%)$ & - & 0,07 \\
\hline 3,3-5,5 ммоль/л & $8(72,73 \%)$ & $15(60,0 \%)$ & $18(52,94 \%)$ & 0,51 \\
\hline$>5,5$ ммоль/л & $1(9,09 \%)$ & $7(28,0 \%)$ & $16(47,06 \%)$ & 0,52 \\
\hline
\end{tabular}

Рівні глюкози крові у процесі лікування пацієнтів з легким $(4,77 \pm 2,21$ ммоль/л) та середнім ступенем тяжкості

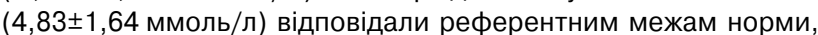
у обстежених з тяжким перебігом залишалися підвищеними $(6,18 \pm 2,97$ ммоль/л), відмінність між показниками статистично значуща $(p=0,03)$. У більшості обстежених усіх груп $-9(81,82 \%)$ з легким, $21(84,0 \%)$ з середнім та 18 (52,94\%) з тяжким перебігом значення глюкози відповідали референтним межам, при порівнянні зареєстровано достовірну відмінність між показниками $(p=0,03)$. Ознаки гіпоглікемії відзначали у $4(5,71 \%)$ обстежених: у 1 (9,09\%) пацієнта з легким, 2 (8,0\%) - із середнім та 1 (2,94\%) з тяжким перебігом ГП; достовірної відмінності не встановлено $(p=0,62)$. У $15(44,12 \%)$ пацієнтів з тяжким, $2(8,0 \%)$ із середнім та $1(9,09 \%)-3$ легким перебігом ГП відзначено прояви гіперглікемії, при порівнянні показників встановлено статистично значущу відмінність значень $(p=0,003)$. Між значеннями глюкози крові у процесі лікування та ступенем тяжкості ГП встановлено прямий слабкий кореляційний зв'язок ( $\tau=0,26 ; p=0,001)$, який підтверджує достовірне підвищення рівня глюкози крові у пацієнтів зі зростанням ступеня тяжкості запального процесу.
Після проведеного лікування у більшості пацієнтів $42(58,57 \%)$ - рівень глюкози знаходився в межах референтних значень. Ознаки гіперглікемії зберігалися у 24 (34,29\%), гіпоглікемії - у 5 (7,14\%) обстежених. Середній рівень глю-

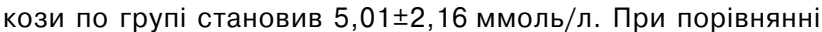
показників глюкози після проведеного лікування у групах пацієнтів з урахуванням ступеня тяжкості ГП статистично значущої різниці між показниками не встановлено $(p=0,08)$. Однак між показниками глюкози крові та ступенем тяжкості ГП виявлено наявність прямого слабкого кореляційного зв'язку $(\tau=0,20 ; p=0,01)$, який підтверджує достовірне підвищення рівня глікемії у пацієнтів зі зростанням тяжкості перебігу захворювання.

На основі логістичного регресійного аналізу достовірно вищі шанси легкого перебігу аліментарного ГП спостерігали у пацієнтів з показниками ПН <7\% (ВШ 6,19; 95\% ДІ 1,45-26,42; p=0,01), амілази <64 од. (ВШ 4,25; 95\% ДІ 1,09-16,56; p=0,03) та глюкози крові <3,3 ммоль/л (ВШ 10,69; 95\% ДІ 1,49-76,73; $\mathrm{p}=0,02)$ при первинному зверненні та аналогічними значеннями ПН (ВШ 5,13; 95\% ДІ 1,28-20,52; $p=0,02)$ й амілази (ВШ $11,07 ; 95 \%$ ДІ 1,28-95,68; $p=0,004)$ протягом лікування. Натомість пацієнти зі значеннями ПН >7\% (ВШ 0,16; 95\% ДІ $0,04-0,69 ; p=0,01$ ) та амілази $>64$ од. (ВШ 0,24; 95\% ДІ $0,06-0,92 ; p=0,03$ ) при первинному зверненні та аналогічними показниками у процесі лікування (ВШ 0,19; 95\% ДІ 0,05-0,78; $\mathrm{p}=0,02)$ та (ВШ 0,09; 95\% ДІ 0,01-0,78; $p=0,004$ ) відповідно мали достовірно нижчі шанси розвитку легкого перебігу ГП (табл. 4).

Таблиця 4. Прогнозування легкого перебігу аліментарного ГП на основі лабораторних показників

\begin{tabular}{|c|c|c|c|c|c|c|}
\hline \multirow{2}{*}{$\begin{array}{c}\text { 3начен- } \\
\text { ня }\end{array}$} & \multicolumn{2}{|c|}{ 1-ше вимірювання } & \multicolumn{2}{|c|}{ 2-ге вимірювання } & \multicolumn{2}{|c|}{ 3-тє вимірювання } \\
\hline & ВШ & $\mathbf{p}$ & ВШ & $p$ & ВШ & $p$ \\
\hline \multicolumn{7}{|c|}{$\Pi \mathrm{H}, \%$} \\
\hline $1-6$ & $\begin{array}{c}6,19 \\
(1,45-26,42)\end{array}$ & $0,01^{*}$ & $\begin{array}{c}5,13 \\
(1,28-20,52)\end{array}$ & $0,02^{*}$ & & 0,09 \\
\hline$\geqslant 7$ & $\begin{array}{c}0,16 \\
(0,04-0,69)\end{array}$ & $0,01^{*}$ & $\begin{array}{c}0,19 \\
(0,05-0,78)\end{array}$ & $0,02^{*}$ & & 0,09 \\
\hline$\leqslant 64$ & $\begin{array}{c}4,25 \\
(1,09-16,56)\end{array}$ & $0,03^{\star}$ & $\begin{array}{c}\text { Амілаза, од. } \\
11,07 \\
(1,28-95,68)\end{array}$ & $0,004^{*}$ & & 0,23 \\
\hline$>64$ & $\begin{array}{c}0,24 \\
(0,06-0,92)\end{array}$ & $0,03^{*}$ & $\begin{array}{c}0,09 \\
(0,01-0,78)\end{array}$ & $0,004^{*}$ & & 0,23 \\
\hline \multicolumn{7}{|c|}{ Глюкоза, ммоль/л } \\
\hline$<3,3$ & $\begin{array}{c}10,69 \\
(1,49-76,73)\end{array}$ & $0,02^{*}$ & & 0,62 & & 0,17 \\
\hline $\begin{array}{l}3,3-5,5 \\
>5,5\end{array}$ & $\begin{array}{c}0,20 \\
(0,04-1,04)\end{array}$ & $\begin{array}{l}0,52 \\
0,03^{*}\end{array}$ & & $\begin{array}{l}0,28 \\
0,13\end{array}$ & $\begin{array}{c}0,16 \\
(0,02-1,36)\end{array}$ & $\begin{array}{l}0,29 \\
0,04^{*}\end{array}$ \\
\hline
\end{tabular}

Розвиток аліментарного ГП середнього ступеня тяжкості асоційований із показниками глюкози, які відповідали референтним значенням норми як при первинному вимірюванні (ВШ 3,22; 95\% ДІ 1,14-9,10; $p=0,02$ ), так і в процесі лікування (ВШ 3,5; 95\% ДІ 1,01-12,17; p=0,03). Натомість пацієнти, рівень глюкози яких залишався підвищеним у процесі лікування, мали достовірно нижчі шанси розвитку ГП середнього ступеня тяжкості (ВШ 0,16; 95\% ДІ 0,03-0,78; $p=0,007$ ) (табл. 5).

Таблиця 5. Прогнозування середнього ступеня тяжкості аліментарного ГП на основі лабораторних показників

\begin{tabular}{|c|c|c|c|c|c|c|}
\hline \multirow{2}{*}{$\begin{array}{c}\text { Значен- } \\
\text { ня }\end{array}$} & \multicolumn{2}{|c|}{ 1-ше вимірювання } & \multicolumn{2}{|c|}{ 2-ге вимірювання } & \multicolumn{2}{|c|}{ 3-тє вимірювання } \\
\hline & ВШ & $p$ & ВШ & $p$ & ВШ & $p$ \\
\hline \multicolumn{7}{|c|}{$\mathrm{nH}, \%$} \\
\hline $1-6$ & & 0,64 & & 0,25 & & 0,11 \\
\hline$\geqslant 7$ & & 0,64 & & 0,25 & & 0,11 \\
\hline \multicolumn{7}{|c|}{ Амілаза, од. } \\
\hline$\leqslant 64$ & & 0,22 & & 0,47 & & 0,64 \\
\hline$>64$ & & 0,22 & & 0,47 & & 0,64 \\
\hline \multicolumn{7}{|c|}{ Глюкоза, ммоль/л } \\
\hline$<3,3$ & & 0,43 & & 0,55 & & 0,25 \\
\hline $3,3-5,5$ & $\begin{array}{c}3,22 \\
(1,14-9,10)\end{array}$ & $0,02^{*}$ & $\begin{array}{c}3,5 \\
(1,01-12,17)\end{array}$ & $0,03^{*}$ & & 0,86 \\
\hline$>5,5$ & & 0,06 & $\begin{array}{c}0,16 \\
(0,03-0,78)\end{array}$ & $0,007^{*}$ & & 0,41 \\
\hline
\end{tabular}

Достовірно вищі шанси тяжкого перебігу аліментарного ГП встановлено у пацієнтів із підвищеними показниками ПН при первинному вимірюванні (ВШ 6,15; 95\% ДІ 1,20-31,51; $\mathrm{p}=0,01$ ), 
протягом лікування (ВШ 5,19; 95\% ДІ 1,61-16,78; $\mathrm{p}=0,003$ ) і по його завершенню (ВШ 9,07; 95\% ДІ 1,01-81,37; p=0,01) (табл. 6).

Значення амілази >64 од. до початку терапії (ВШ 5,36; 95\% ДІ $1,52-18,85 ; p=0,004$ ) та протягом лікування (ВШ 3,67; 95\% ДІ $1,34-10,07 ; p=0,008)$ також пов'язані з достовірно вищими шансами тяжкого перебігу аліментарного ГП. У пацієнтів з аліментарним ГП гіперглікемія при первинному зверненні (ВШ 5,44; 95\% ДІ 1,92-15,42; p=0,007), у процесі лікування (ВШ 8,68; 95\% ДІ $2,17-34,75 ; p=0,0004)$ та по його завершенні (ВШ 3,11;95\% ДІ $1,08-8,92 ; p=0,03)$ також асоційована з достовірно вищим ризиком тяжкого перебігу захворювання. Нижча вірогідність тяжкого перебігу аліментарного ГП у пацієнтів, значення ПН, амілази і глюкози яких відповідали референтним показниками при первинному вимірюванні та протягом лікування $(p<0,05)$. Крім того, низький ризик тяжкого перебігу встановлено у хворих із показниками глюкози $<3,3$ ммоль/л на завершальному етапі лікування (ВШ 0,16; 95\% ДІ 0,06-0,42; p=0,008).

Таблиця 6. Прогнозування тяжкого перебігу аліментарного ГП на основі лабораторних показників

\begin{tabular}{|c|c|c|c|c|c|c|}
\hline \multirow{2}{*}{$\begin{array}{c}\text { Значен- } \\
\text { ня }\end{array}$} & \multicolumn{2}{|c|}{ 1-ше вимірювання } & \multicolumn{2}{|c|}{ 2-ге вимірювання } & \multicolumn{2}{|c|}{ 3-тє вимірювання } \\
\hline & ВШ & $p$ & ВШ & $p$ & ВШ & $p$ \\
\hline \multicolumn{7}{|c|}{ ПН, \% } \\
\hline $1-6$ & $\begin{array}{c}0,16 \\
(0,03-0,83)\end{array}$ & $0,01^{*}$ & $\begin{array}{c}0,19 \\
(0,06-0,62)\end{array}$ & $0,003^{*}$ & $\begin{array}{c}0,11 \\
(0,01-0,99)\end{array}$ & $0,01^{*}$ \\
\hline$\geqslant 7$ & $\begin{array}{c}6,15 \\
(1,20-31,51)\end{array}$ & $0,01^{*}$ & $\begin{array}{c}5,19 \\
(1,61-16,78)\end{array}$ & $0,003^{*}$ & $\begin{array}{c}9,07 \\
(1,01-81,37)\end{array}$ & $0,01^{*}$ \\
\hline \multicolumn{7}{|c|}{ Амілаза, од. } \\
\hline$\leqslant 64$ & $\begin{array}{c}0,19 \\
(0,05-0,66)\end{array}$ & $0,004^{*}$ & $\begin{array}{c}0,27 \\
(0,10-0,75)\end{array}$ & $0,008^{*}$ & & 0,27 \\
\hline$>64$ & $\begin{array}{c}5,36 \\
(1,52-18,85)\end{array}$ & $0,004^{*}$ & $\begin{array}{c}3,67 \\
(1,34-10,07)\end{array}$ & $0,008^{\star}$ & & 0,27 \\
\hline \multicolumn{7}{|c|}{ Глюкоза, ммоль/л } \\
\hline$<3,3$ & & 0,17 & & 0,32 & $\begin{array}{c}0,16 \\
(0,06-0,42)\end{array}$ & $0,008^{*}$ \\
\hline $3,3-5,5$ & $\begin{array}{c}0,26 \\
(0,10-0,73)\end{array}$ & $0,007^{\star}$ & $\begin{array}{c}0,23 \\
(0,07-0,69)\end{array}$ & $0,006^{*}$ & & 0,35 \\
\hline$>5,5$ & $\begin{array}{c}5,44 \\
(1,92-15,42)\end{array}$ & $0,007^{*}$ & $\begin{array}{c}8,68 \\
(2,17-34,75)\end{array}$ & $0,0004^{*}$ & $\begin{array}{c}3,11 \\
(1,08-8,92)\end{array}$ & $0,03^{*}$ \\
\hline
\end{tabular}

\section{Висновки}

1. Оцінюючи рівні ПН, амілази та глюкози крові у пацієнтів з аліментарним ГП з урахуванням тяжкості перебігу, встановлено достовірну відмінність показників у групах при повторних вимірюваннях.

2. Наявність кореляційних зв'язків між ступенем тяжкості ГП та значеннями досліджуваних лабораторних показників свідчить про достовірне зростання лабораторних показників з підвищенням тяжкості перебігу ГП на різних етапах вимірювання.

3. Встановлено високу інформативність лабораторних показників у прогнозуванні тяжкості перебігу ГП, навіть за їх низької органної специфічності щодо ураження ПЗ.

\section{Список використаної літератури}

Гончаров М.П., Шведа Ю.І. (2016) Аналітична оцінка хірургічного лікування гострого панкреатиту. Вісн. пробл. біол. мед., 1(126): 151-156.

Cho J.H., Kim T.N., Chung H.H., Kim K.H. (2015) Comparison of scoring systems in predicting the severity of acute pancreatitis. World J. Gastroenterol., 21(8): 2387-2394.

Greenberg J.A., Hsu J., Bawazeer M. et al. (2016) Clinical practice guideline: management of acute pancreatitis. Can. J. Surg., 59(2): 128-140.

Karakayali F.Y. (2014) Surgical and interventional management of complications caused by acute pancreatitis. World J. Gastroenterol., 20(37): 13412-13423.

Manohar M., Verma A.K., Venkateshaiah S.U. et al. (2017) Pathogenic mechanisms of pancreatitis. World J. Gastrointest. Pharmacol. Therapeut., 8(1): 10-25.

Petrov M.S., Yadav D. (2019) Global epidemiology and holistic prevention of pancreatitis. Nat. Rev. Gastroenterol. Hepatol., 16(3): 175-184.

Rompianesi G., Hann A., Komolafe O. et al. (2017) Serum amylase and lipase and urinary trypsinogen and amylase for diagnosis of acute pancreatitis. The Cochrane database of systematic reviews, 4(4): CD012010.

Shah A.P., Mourad M.M., Bramhall S.R. (2018) Acute pancreatitis: current perspectives on diagnosis and management. J. Inflam. Res., 11: 77-85.

Staubli S.M., Oertli D., Nebiker C.A. (2015) Laboratory markers predicting severity of acute pancreatitis. Crit. Rev. Clin. Lab. Sci., 52(6): 273-283. van Dijk S.M., Hallensleben N.D.L., van Santvoort H.C. et al.; Dutch Pancreatitis Study Group (2017) Acute pancreatitis: recent advances through randomised trials. Gut., 66(11): 2024-2032.

\section{Прогнозирование тяжести течения острого алиментарного панкреатита на основании лабораторных показателей}

\section{Ю.В. Авдосьев, К.М. Панькив}

Резюме. Цель - оценить изменение лабораторных показателей у пациентов с острым панкреатитом (ОП) алиментарного генеза при повторных измерениях и определить их роль в прогнозировании тяжести течения. Объект и методы исследования. Обследовано 70 пациентов с ОП алиментарного генеза (средний возраст -

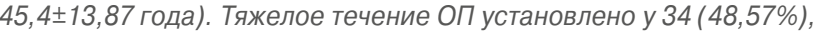
среднее - у 25(35,72\%), легкое - у 11(15,71\%) лиц. Тяжесть течения ОП оценивали с помощью классификации Атланта 2012 г. Для прогнозирования тяжести течения производили повторные измерения уровней палочкоядерных нейтрофилов, амилазы и глюкозы. Результаты. Достоверно более высоки шансы легкого течения ОП у пациентов со значениями палочкоядерных нейтрофилов <7\%, амилазы <64 ед. иглюкозы <3,3 ммоль/л, установленными при первичном обращении и на протяжении лечения. Доказанный прогностический критерий средней степени тяжести - значение глюкозы 3,3-5,5 ммоль/л при первичном измерении и в процессе лечения. у больных со значениями палочкоядерных нейтрофилов $\geqslant 7 \%$, амилазы >64 ед. и глюкозы $\geqslant 5,5$ ммоль/л при первичном измерении и в процессе лечения достоверно более высока вероятность тяжелого течения заболевания. Критериями тяжелого течения также являются повышенные уровни палочкоядерных нейтрофилов иглюкозы после окончания лечения. Выводы. Доказана высокая информативность лабораторных показателей в прогнозировании тяжести ОП и их достоверное отличие в исследуемых группах

Ключевые слова: острый алиментарный панкреатит, прогнозирование тяжести течения острого панкреатита, степень тяжести острого панкреатита, лабораторные показатели.

\section{Severity prediction of acute alimentary pancreatitis based on laboratory parameters}

\section{Yu.V. Avdosiev, K.M. Pankiv}

Summary. Aim - to evaluate changes of laboratory parameters in patients with alimentary acute pancreatitis $(A P)$ based on repeated measurements and to determine their role in severity prediction. Object and research methods. Seventy patients with alimentary AP were examined(average age of $45.4 \pm 13.87$ years). Severe pancreatitis was found in $34(48.57 \%)$, moderate - in 25(35.72\%), mild - in 11(15.71\%) people. The severity of the $A P$ was assessed using the Atlanta classification (2012). To predict the severity of $A P$ repeated measurements of the levels of rod neutrophils, amylase, and glucose were performed. Results. Significantly higher chances of mild course of AP were found in patients with values of rod neutrophils $<7 \%$, amylase $<64$ units and glucose $<3.3 \mathrm{mmol} / \mathrm{l}$ established in the initial measurement and during treatment. Proved medium-term prognostic criteria are glucose values of 3.3-5.5 mmol/l in the initial measurement and during treatment. In patients with rod neutrophil values $\geqslant 7 \%$, amylase $>64$ units and glucose $\geqslant 5.5 \mathrm{mmol} /$ lat the initial measurement and during treatment proved significantly higher chances of forming a severe disease course. Difficulty criteria are also increased levels of rod neutrophils and glucose established after treatment completion. Conclusions. High informativeness of laboratory parameters in the severity prediction of $A P$ and their significant difference in the studied groups have been proved.

Key words: acute alimentary pancreatitis, severity prediction of acute pancreatitis, the severity of acute pancreatitis, laboratory parameters.

\section{Адреса для листування:}

Паньків Катерина Михайлівна

21000, Вінниця, вул. Пирогова, 56

Вінницький національний медичний

університет імені М.І. Пирогова,

кафедра ендоскопічної та серцево-судинної хірургії

E-mail: kateryna.pankiv@gmail.com 